Teologia i Moralność, volumen 12(2017), numer 2(22)

doi: 10.14746/tim.2017.22.2.8

JANUSZ GADZINOWSKI

Uniwersytet Medyczny w Poznaniu im. Karola Marcinkowskiego

Katedra i Klinika Neonatologii

\title{
Poczęcie naturalne, in vitro i „NaPro”
}

Niepłodność małżeńska występuje od zarania ludzkości. Wspomina o niej na przykład Stary Testament. W tamtych czasach stanowiła bardzo duży problem, ponieważ $\mathrm{w}$ starożytnej Palestynie uważano ją za przekleństwo od Boga, a z praktycznego punktu widzenia przy braku systemu emerytalnego oznaczała trudną starość.

Obecnie częstość występowania niepłodności małżeńskiej w Polsce sięga ok. $20 \%$, taka częstość podawana jest od wielu lat, choć nie ma obiektywnych badań na ten temat. W USA wynosi ona $7 \%{ }^{1}$.

Pewne przyczyny niepłodności występują od zawsze, choć zmieniła się częstość chorób, które mogą ją spowodować. Pojawiły się jednak nowe powody, można powiedzieć, „cywilizacyjne”. Należy do nich przede wszystkim późniejszy wiek kobiet, które chcą rodzić po raz pierwszy, ponieważ płodność spada wraz z wiekiem. Istnieją także i takie przyczyny zarówno u kobiet, jak i u mężczyzn, które można ograniczyć poprzez odpowiednie programy profilaktyczne.

W naturalnych okolicznościach $\mathrm{u}$ dojrzewających dziewcząt $\mathrm{w}$ następstwie sygnału z części mózgu zwanego podwzgórzem przysadka mózgowa zaczyna wydzielać hormony gonadotropowe, które poprzez wpływ na jajniki stymulują wydzielanie przez nie hormonów steroidów płciowych. Te poprzez krwioobieg dostają się do przysadki mózgowej, która stymulowana jest przez nie do wydzielania swoich hormonów. Na tej podstawie ustala się miesięczny cykl płciowy. W toku tego cyklu w czasie owulacji z jajnika wydostaje się komórka jajowa, która zostaje uchwycona przez strzępki jajowodu i rozpoczyna wędrówkę w stronę macicy, przesuwana przez rzęski i skurcze jajowodu.

${ }^{1}$ A. Chandra i in., Fertility, family planning, and reproductive health of U.S. women: data from the 2002 National Survey of Family Growth, Vital Health Stat 23. 2005 Dec;(25), s. 1-160 
U kobiety, która współżyje płciowo, komórka jajowa może być zapłodniona przez jedną dobę i dzieje się to w pobliżu jajnika. Plemniki zachowują swoją zdolność do zapłodnienia przez około 5 dni. Jednak dojść do niego może tylko, jeśli znajdą się one w odpowiednim czasie we właściwym miejscu oraz jeśli przejdą przedtem złożony proces selekcji (z blisko 500 tys. plemników w jednej ejakulacji potrzebny jest tylko jeden) i dojrzewania. W momencie gdy jeden plemnik przedostanie się do wnętrza komórki jajowej, zostaje zablokowana możliwość wniknięcia tam innych. W momencie zapłodnienia z komórki jajowej powstaje zygota, która rozpoczyna „wędrówkę” w kierunku macicy przesuwana ruchami rzęsek w jajowodzie wspomaganych jego skurczami. W tym procesie pomaga także ruch witek plemników, które nie wniknęły całkowicie do wnętrza komórki jajowej. Po około 8 dniach blastocysta, która powstała z zygoty, zagnieżdża się w macicy. Przedmaciczny rozwój człowieka może odbyć się w laboratorium, później jednak rozpoczyna się okres wewnątrzmaciczny, który może przebiegać wyłącznie w organizmie kobiety.

\section{Techniki wspomagania reprodukcji (assisted reproductive technologies ART)}

$\mathrm{W}$ jednej $\mathrm{z}$ technik wspomagania reprodukcji, $\mathrm{w}$ uproszczeniu $\mathrm{w}$ procesie in vitro, ,zastępując" przysadkę mózgową podaje się większe niż fizjologiczne dawki hormonów gonadotropowych, doprowadzając do wydzielenia kilkunastu komórek jajowych. Potrzebne jest to w celu zwiększenia skuteczności całego procesu. Pobiera się je później z organizmu kobiety i przenosi do laboratorium. Do zapłodnienia dochodzi poza organizmem kobiety plemnikami, których dojrzewanie i selekcja odbywa się w laboratorium. Tym samym faza przedmacicznego rozwoju istoty ludzkiej przemieszczona zostaje poza naturalne środowisko, jakim jest organizm kobiety, a plemniki poddane zostają manipulacjom człowieka. Później następuje wybór zarodka, który ma się rozwijać. Może on być poddany mikromanipulacjom, takim jak diagnostyka przedimplatacyjna przez pobranie komórek i poddanie ich badaniom genetycznym i inne. Większość zarodków jest zamrażana, a ich dalsze losy nie są dokładnie znane.

Ocenia się, iż wyżej opisywane techniki laboratoryjne odpowiadają za do $10 \%$ z blisko $30 \%$ wzrostu częstości występowania wad wrodzonych w populacji dzieci poczętych in vitro $\mathrm{w}$ porównaniu $\mathrm{z}$ poczętymi naturalnie ${ }^{2}$. Po-

${ }^{2}$ Częstość występowania wad cytuję za Joe Simpson w-ce Przewodniczącym March of Dimes - fundacji zajmującej się wadami wrodzonymi w USA. Inne publikacje informują o różnie częstym występowaniu wad wrodzonych u noworodków poczętych zarówno in vitro jak i po 
docytoplazmatycznym wstrzyknięciu plemnika do jajeczka w porównaniu z poczęciem naturalnym. Zależy to od odmienności $\mathrm{w}$ badanych populacjach $\mathrm{w}$ tym udziale wewnątrzmacicznych zgonów zarodków i płodów występujących samoistnie jak i w następstwie działań człowieka. K.J. Barrington, A. Janvier, The paediatric consequences of Assisted Reproductive Technologies, with special emphasis on multiple pregnancies, Acta Paediatr. 2013 Apr;102(4), s. 340-348; K.T. Barnhart, Assisted reproductive technologies and perinatal morbidity: interrogating the association, Fertil Steril. 2013 Feb;99(2), s. 299-302; C. Bouillon, P. Fauque, Follow-up of children conceived by assisted reproductive technologies, Arch Pediatr. 2013 May; 20 (5), s. 575-579; W.M. Buckett i in., Obstetric outcomes and congenital abnormalities after in vitro maturation, in vitro fertilization, and intracytoplasmic sperm injection, Obstet Gynecol. 2007 Oct;110(4), s. 885-91; M.J. Davies, i in., Reproductive technologies and the risk of birth defects, N Engl J Med. 2012 May 10;366(19), s. 1803-1813; S. Epelboin i in., Health and development of children conceived through assisted reproductive technologies, Rev Prat. 2014 Jan;64(1), s. 102-105; Review. French; M. Farhangniya i in., Comparison of Congenital Abnormalities of Infants Conceived by Assisted Reproductive Techniques versus Infants with Natural Conception in Tehran, Int J Fertil Steril. 2013 Oct;7(3), s. 217-224; O. Finnström i in., Maternal and child outcome after in vitro fertilization - a review of 25 years of population-based data from Sweden, Acta Obstet Gynecol Scand. 2011 May;90(5), s. 494-500; J. Gadzinowski i in., In vitro babies - medical and legal aspects: a European and North American perspective, BioTechnologia vol. 93(1) C pp. 9-26 C 2012; V.V. Grabar, Interconnection between assisted reproductive technologies, pregnancy complications and risk of birth defects, Georgian Med News. 2014 Feb;(227), s. 7-14; P. Gupta i in., Perinatal outcomes among children born by assisted reproductive techniques-a hospital-based case control study, Med J Armed Forces India. 2012 Apr;68(2), s. 132-135; M. Hansen, C. Bower, The impact of assisted reproductive technologies on intra-uterine growth and birth defects in singletons, Semin Fetal Neonatal Med. 2014 Aug;19(4), s. 228-233; M. Hansen i in., Assisted reproductive technologies and the risk of birth defects--a systematic review, Hum Reprod. 2005 Feb;20(2), s. 328338. Epub 2004 Nov 26; A.S. Heisey i in., Surveillance of congenital malformations in infants conceived through assisted reproductive technology or other fertility treatments, Birth Defects Res A Clin Mol Teratol. 2015 Feb;103(2), s. 119-126; A.K. Henningsen i in., The prognosis for children born after assisted reproduction, Ugeskr Laeger. 2012 Oct 8;174(41), s. 2462-2466; T.W. Hilgers, The medical and surgical practice of NaProTechnology, Pope Paul VI Institute Press, Omaha, NE 2004; M. Hyrapetian i in., Health and disease in children born after assistive reproductive therapies, J Reprod Immunol. 2014 Dec;106, s. 21-26; B. Källén i in., Congenital malformations in infants born after in vitro fertilization in Sweden, Birth Defects Res A Clin Mol Teratol. 2010 Mar;88(3), s. 137-143; L.I. Kelley-Quon i in., Congenital malformations associated with assisted reproductive technology: a California statewide analysis, J Pediatr Surg. 2013 Jun;48(6), s. 1218-1224; T.A.Merritt $\mathrm{i}$ in., Impact of ART on pregnancies in California: an analysis of maternity outcomes and insights into the added burden of neonatal intensive care, J Perinatol. 2014 May;34(5), s. 345-350; R. Mozafari Kermani i in., Congenital anomalies in infants conceived by assisted reproductive techniques, Arch Iran Med. 2012 Apr;15(4), s. 228-231; S. Ooki, Birth defects in singleton versus multiple ART births in Japan (2004-2008), J Pregnancy. 2011;2011, s. 285706; A. Pinborg i in., Congenital anomalies after assisted reproductive technology, Fertil Steril. 2013 Feb;99(2), s. 327332; J. Reefhuis i in., Assisted reproductive technology and major structural birth defects in the United States, National Birth Defects Prevention Study, Hum Reprod. 2009 Feb;24(2), s. 360-366; D. Skora, D. Frankfurter, Adverse perinatal events associated with ART, Semin Reprod Med. 2012 Apr;30(2), s. 84-91; K. Tararbit i in., EPICARD Study Group, The risk for four specific congenital heart defects associated with assisted reproductive techniques: a population-based evaluation, Hum Reprod. 2013 Feb;28(2), s. 367-374; K.J. Barrington, A. Janvier, The paediatric consequences of Assisted Reproductive Technologies, with special emphasis on multiple pregnancies, Acta Paediatr. 2013 Apr;102(4), s. 340-348; N.R. Vulliemoz i in., In Vitro Fertilisation: Perinatal Risks and Early 
zostałe $20 \%$ spowodowane jest przezwyciężeniem niepłodności spowodowanej zaawansowanym wiekiem rodziców, problemami genetycznymi i innymi czynnikami ${ }^{3}$.

Jak wynika z amerykańskich badań Merritta ${ }^{4}$, poza wzrostem częstości występowania wad wrodzonych w ciążach poczętych przy użyciu metod wspomagania rozrodu (ART) i wspomaganej inseminacji (assisted insemination / AI) stwierdza się 4-5-krotny wzrost obumarć płodu, przy 2-3-krotnym wzroście po leczeniu niepłodności innymi sposobami, w porównaniu z poczęciami naturalnymi. Czterokrotnie częściej ciąże te zakończone są cięciem cesarskim. Czterokrotnie częściej występują porody przedwczesne. W ciążach poczętych po ART/AI stwierdza się 24-27-krotny wzrost występowania ciąż mnogich w porównaniu do naturalnego poczęcia przy 2-3-krotnym po leczeniu niepłodności innymi metodami. Długość pobytu matki w szpitalu oraz koszt leczenia noworodków wzrasta kilkukrotnie w przypadku ciąż pojedynczych i wielopłodowych w porównaniu do noworodków z ciąż poczętych naturalnie.

Istnieje teoria Bakera o rozwojowym pochodzeniu chorób dorosłych. Jeżeli jest ona prawdziwa, to - być może - tłumaczy to częstsze występowanie podwyższonego ciśnienia krwi, podwyższonego poziomu glukozy we krwi, starszego wieku kostnego, zaburzeń dystrybucji tłuszczu i zaburzeń funkcji tarczycy u ludzi dorosłych poczętych za pomocą in vitro ${ }^{5}$.

U dzieci po ART stwierdzono częstsze występowanie pewnych zespołów epigenetycznych ${ }^{6}$. Ma to znaczenie medyczne, nie ma jednak obecnie znaczenia dla populacji ludzkiej ze względu na rzadkie występowanie.

Childhood Outcomes, Hum Fertil (Camb). 2012 Jun;15(2), s. 62-68; L. Yin L. i in, Analysis of birth defects among children 3 years after conception through assisted reproductive technology in China, Birth Defects Res A Clin Mol Teratol. 2013 Nov;97(11), s. 744-749.

${ }^{3}$ R. Hua $\mathrm{i}$ in., Occupational, educational and residential factors are associated with the outcomes of in vitro fertilization-embryo transfer, Nan Fang Yi Ke Da Xue Xue Bao. 2016 Jan;36(1), s. 44-49; L.A. Humphries i in., Influence of race and ethnicity on in vitro fertilization outcomes: systematic review, Am J Obstet Gynecol. 2016 Feb;214(2), s. 212.e1-212.e17.

${ }^{4}$ T.A. Merritt $\mathrm{i}$ in., Impact of ART on pregnancies in California.

${ }^{5} \mathrm{M}$. Ceelen i in., Growth during infancy and early childhood in relation to blood pressure and body fat measures at age 8-18 years of IVF children and spontaneously conceived controls born to subfertile parents, Hum Reprod. 2009 Nov;24(11), s. 2788-2795; Ceelen M. i in., Pubertal development in children and adolescents born after IVF and spontaneous conception, Hum Reprod. 2008 Dec;23(12), s. 2791-2798; Y.H. Lu i in., Long-term follow-up of children conceived through assisted reproductive technology, J Zhejiang Univ Sci B. 2013 May;14(5), s. 359-371; L.C. Wilson $\mathrm{i}$ in., Looking downstream: a review of the literature on physical and psychosocial health outcomes in adolescents and young adults who were conceived by ART, Hum Reprod. 2011 May; 26(5), s. 1209-1219.

${ }^{6}$ Jeśli zespół epigenetyczny występuje u noworodka z częstotliwością jeden na kilkadziesiąt tysięcy urodzeń to nawet podwojenie jego występowania, jakkolwiek jest dużą tragedią dla dziecka i jego rodziny, pozostaje ciągle rzadkim zjawiskiem medycznym. G. Cocchi i in., Silver-Russell syndrome due to paternal H19/IGF2 hypomethylation in a twin girl born after in vitro fertilization, Am 
Wśród niewielkiej liczby publikacji, które nie potwierdzają zwiększonej zachorowalności u dzieci poczętych metodami in vitro należy bardzo dokładnie sprawdzić, jaka grupa badana jest przedstawiona. Często opisywany jest problem wśród żywo urodzonych dzieci nie uwzględniający poronień spowodowanych wadami, przerwań ciąży z powodu wad, redukcji płodów, obumarć płodów w późnych okresach ciąży. Następstwa in vitro dla dzieci są krytycznie opisane w oryginalnym artykule oraz przedruku polskim przez Royal College of Obstetricians and Gynaecologists oraz British Fertility Society?

Istnieją także doniesienia o zwiększonym ryzyku uszkodzenia na stałe genomu człowieka, czego następstwa ujawnią się w przyszłych generacjach ${ }^{8}$. Teoretycznie może wystąpić także ryzyko kazirodztwa, jako że dawcą plemników dla wielu ciąż może być ten sam mężczyzna.

Niekorzystnym i często występującym następstwem technik wspomagania reprodukcji jest wzrost częstości występowania ciąży wielopłodowej. $\mathrm{W}$ naturalnych okolicznościach ciąże bliźniacze występują $\mathrm{w}$ ok. $1 \%$, po technikach wspomaganej reprodukcji w ok. 20-25\% lub częściej. Po wprowadzeniu w Szwecji zakazu przenoszenia więcej niż 1 zarodka, częstość ciąż wielopłodowych spadła do $5,6 \%$, jednak ciągle pozostaje wyższa niż w oko-

J Med Genet A. 2013 Oct;161A(10), s. 2652-2655; H. Hiura i in., Characterization of DNA methylation errors in patients with imprinting disorders conceived by assisted reproduction technologies, Hum Reprod. 2012 Aug;27(8), s. 2541-2548; L. Hoeijmakers i in., Epigenetic imprinting during assisted reproductive technologies: The effect of temporal and cumulative fluctuations in methionine cycling on the DNA methylation state, Mol Reprod Dev. 2016 Feb;83(2), s. 94-107; M. Kagami i in., SilverRussell syndrome in a girl born after in vitro fertilization: partial hypermethylation at the differentially methylated region of PEG1/MEST, J Assist Reprod Genet. 2007 Apr;24(4), s. 131-136; A. Kochański $\mathrm{i}$ in., The impact of assisted reproductive technologies on the genome and epigenome of the newborn, J Neonatal Perinatal Med. 2013;6(2), s. 101-108; P. Kuentz i in., Child with Beckwith-Wiedemann syndrome born after assisted reproductive techniques to an human immunodeficiency virus serodiscordant couple, Fertil Steril. 2011 Jul;96(1), s. e35-38; V.F. i in., Defects in imprinting and genome-wide DNA methylation are not common in the in vitro fertilization population, Fertil Steril. 2012 Jan;97(1), s. 147-53.e7; E.Y. Jr Strawn i in., Is it the patient or the IVF? Beckwith-Wiedemann syndrome in both spontaneous and assisted reproductive conceptions, Fertil Steril. 2010 Jul;94(2), s. 754.e1-2; A. Uyar, E. Seli, The impact of assisted reproductive technologies on genomic imprinting and imprinting disorders, Curr Opin Obstet Gynecol. 2014 Jun;26(3), s. 210-221; U. Zechner i in., Quantitative methylation analysis of developmentally important genes in human pregnancy losses after ART and spontaneous conception, Mol Hum Reprod. 2010 Sep;16(9), s. 704-713.

${ }^{7}$ N.R. Vulliemoz i in., In Vitro Fertilisation, dz. cyt.

${ }^{8} \mathrm{C}$. Feng i in., Assisted reproductive technology may increase clinical mutation detection in male offspring, Fertil Steril. 2008 Jul;90(1), s. 92-96; A. Kochański i in., The impact of assisted reproductive technologies on the genome.

${ }^{9}$ T.A. Merritt $\mathrm{i}$ in., Impact of ART on pregnancies in California; $\mathrm{S}$. Ooki, Birth defects in singleton versus multiple ART births in Japan (2004-2008); S. Patchava i in., Managing the complications associated with assisted reproductive technologies, Minerva Ginecol. 2009 Aug;61(4), s. 347-355; K.J. Barrington, A. Janvier, The paediatric consequences of Assisted Reproductive Technologies, dz. cyt. 
licznościach naturalnych ${ }^{10}$. Wprawdzie ciąża mnoga występuje w naturze, ale zawsze wiąże się z częstszą patologią i gorszymi wynikami zachorowalności i śmiertelności noworodków, stąd zwiększenie częstości występowania ciąży wielopłodowej jest niekorzystne.

Sytuacje te próbuje się regulować przez redukcję płodów, zabijając „,nadliczbowe" zaimplantowane zarodki i płody ${ }^{11}$.

Ciąże po ART obarczone są częstszym występowaniem skręcenia przydatków u kobiet, następstwami ciąży wielopłodowej (przetoczeniem krwi między bliźniętami) oraz takimi powikłaniami, jak: łożysko przodujące, krwawienie z dróg rodnych, stany zapalne, nadciśnienie, cukrzyca ${ }^{12}$. Częstsze występowanie nowotworów złośliwych u kobiet po przebytym in vitro było niepewne ${ }^{13}$. Ostatnie informacje z Izraela mówią o częstym występowaniu nowotworów złośliwych jajnika i macicy ${ }^{14}$.

${ }^{10}$ O. Finnström i in., Maternal and child outcome after in vitro fertilization; B. Källén i in., Congenital malformations in infants born.

${ }^{11}$ A. Antsaklis i in., Embryo reduction versus expectant management in triplet pregnancies, J Matern Fetal Neonatal Med. 2004 Oct;16(4), s. 219-222; C.U. CheangHYPERLINK "https:// www.ncbi.nlm.nih.gov/pubmed/?term=Cheang\%20CU\%5BAuthor\%5D\&cauthor=true\&cauthor uid $=17270181 " \mathrm{i}$ in., A comparison of the outcomes between twin and reduced twin pregnancies produced through assisted reproduction, Fertil Steril. 2007 Jul;88(1), s. 47-52. Epub 2007 Jan 30; J. Stone i in., A single center experience with 1000 consecutive cases of multifetal pregnancy reduction, Am J Obstet Gynecol. 2002 Nov;187(5), s. 1163-1167; O. Torok i in., Multifetal pregnancy reduction is not associated with an increased risk of intrauterine growth restriction, except for veryhigh-order multiples, Am J Obstet Gynecol. 1998 Jul;179(1), s. 221-225; D.J. Vettori, P. Jairath, $A$ rare presentation of aplasia cutis congenita after feto-reduction in a trichorionic-triamniotic pregnancy, J Neonatal Perinatal Med. 2015;8(3), s. 275-281.

12 Powikłania występujące po zastosowaniu metod wspomagania reprodukcji są w środowisku medycznym lekceważone. Nie informują o tym zazwyczaj ośrodki „in vitro”. W.M. Buckett i in., Obstetric outcomes; A. Chandra i in., Fertility; O. Finnström i in., Maternal and child outcome after in vitro fertilization; G. Neuman, G. Koren, Mothersisk update: reproductive outcomes after assisted conception, Can Fam Physician. 2013 Jan;59(1), s. 33-34, 36; T.C. Plowden i in., Disparities in obstetrical outcomes in ART pregnancies compared with natural conceptions, Semin Reprod Med. 2013 Sep;31(5), s. 340-346; J. Qin i in., Pregnancy-related complications and adverse pregnancy outcomes in multiple pregnancies resulting from assisted reproductive technology: a meta-analysis of cohort studies, Fertil Steril. 2015 Jun;103(6), s. 1492-508.e1-7; D. Skora, D. Frankfurter, Adverse perinatal events; Arendt J. i in., Retrospective studies of pregnancies after assisted medical reproduction from 2001-2009 and Central Hospital in Luxembourg (part 2), Bull Soc Sci Med Grand Duche Luxemb. 2010;(2), s. 257-270

${ }^{13} \mathrm{M}$. Lambertini i in., Cancer and fertility preservation: international recommendations from an expert meeting, BMC Med. 2016; 14:1.Published online 2016 Jan 4G; Neuman, G. Koren, Mothersisk update; I. Rizzuto i in., Risk of ovarian cancer in women treated with ovarian stimulating drugs for infertility, Cochrane Database Syst Rev. 2013 Aug 13;(8):CD008215; J. Schneider i in., Long-term breast cancer risk following ovarian stimulation in young egg donors: a call for followup, research and informed consent, Reprod Biomed Online. 2017 May;34(5), s. 480-485.

${ }^{14} \mathrm{R}$. Kessous $\mathrm{i}$ in., The risk of female malignancies after fertility treatments: a cohort study with 25-year follow-up, J Cancer Res Clin Oncol. 2016 Jan;142(1), s. 287-293. 
W związku z przekraczaniem fizjologicznych poziomów hormonów przysadkowych ważną konsekwencją ART jest także możliwość wystąpienia choroby zespołu hiperstymulacji jajników (u 1-2\% kobiet) - pewien odsetek kobiet $\mathrm{z}$ tego powodu umiera ${ }^{15}$.

Częstszy po ART jest poród przedwczesny, o czym informuje szereg publikacji ${ }^{16}$. Należy wspomnieć, że w Szwecji, kraju o bardzo wysokim poziomie medycyny perinatalnej, poród przedwczesny występuje po IVF w $7,5 \%$, po zapłodnieniu naturalnym $5,1 \%$, hipotrofia wewnątrzmaciczna po IVF - 3,3\%, w naturze $2,1 \%{ }^{17}$.

Metody ART/AI określane często łącznie jako in vitro nie są akceptowane przez kościół katolicki. Główną tego przyczyną jest obarczenie metody eliminacją zarodków, rozumiane jako zabijanie istot ludzkich.

\section{Technika wspomagania prokreacji (Natural Procreactive Technology - NaPro)}

Istnieje bardzo ważna alternatywa dla in vitro. Jest nią naprotechnologia (NaPro), czyli usystematyzowany zbiór metod rozpoznawania i leczenia niepłodności. Jest to leczenie nowoczesne, oparte na szeregu sprawdzonych i znanych sposobów postępowania. Dla ludzi wierzących ważny jest fakt, iż jest ona akceptowana przez Kościół katolicki.

NaPro została zaproponowana przez T. Hilgersa jako system prokreacji a nie reprodukcji (całość nazwy to natural procreative technology w przeciwieństwie do associated reproductive technology - ART, w tym in vitro $)^{18}$.

Ważnymi cechami naprotechnologii jest to, że jest systemem leczenia i całościowej troski o zdrowie kobiety bez omijania przyczyn niepłodności. Opie-

${ }^{15}$ S. Patchava i in., Managing the complications associated with assisted reproductive technologies.

${ }^{16}$ C. Bouillon, P. Fauque, Follow-up of children conceived by assisted reproductive technologies, Arch Pediatr. 2013 May; 20 (5), s. 575-579; P. Gupta i in., Perinatal outcomes among children born by assisted reproductive techniques-a hospital-based case control study, Med J Armed Forces India. 2012 Apr;68(2), s. 132-135; M. Hansen, C. Bower, The impact of assisted reproductive technologies on intra-uterine growth and birth defects in singletons, Semin Fetal Neonatal Med. 2014 Aug;19(4), s. 228-233; A.K. Henningsen i in., The prognosis for children born after assisted reproduction, Ugeskr Laeger. 2012 Oct 8;174(41), s. 2462-2466; T.A. Merritt i in., Impact of ART on pregnancies in California.

${ }^{17} \mathrm{O}$. Finnström i in., Maternal and child outcome after in vitro fertilization.

${ }^{18}$ Metoda NaPro jest licencjonowana. Ma to dobrą stronę, bo utrzymuje dyscyplinę w jej stosowaniu, ale i złą stronę, że jej rozwój jest powolny. Popularna staje się coraz bardziej medycyna reperacyjna - leczenie niepłodności uznanymi metodami ale z uszanowaniem nauczania Kościoła katolickiego. T.W. Hilgers, The medical and surgical practice of NaProTechnology, Pope Paul VI Institute Press, Omaha, NE 2004. 
ra się ona na bardzo dokładnej obserwacji cyklu miesięcznego kobiety i łączy najnowocześniejsze osiągnięcia ginekologii, chirurgii i endokrynologii. Inną ważną sprawą jest to, że jej wykonawcami są nie tylko lekarz, ale i instruktor, który prowadzi wstępne rozpoznanie przyczyn niepłodności.

Naprotechnologia narzuca systematyczny proces rozpoznawania przyczyn i leczenia niepłodności - jest to ważna różnica w porównaniu z tradycyjnym postępowaniem w niepłodności, który jest mniej uporządkowany. Rozpoczyna się od CrMS (Creighton Model of Fertility), który jest typowy tylko dla naprotechnologii, we współpracy pary małżeńskiej z instruktorem. Część par z niepłodnością ulega wyleczeniu, tj. kobieta zachodzi w ciążę w następstwie aktu seksualnego celowanego na owulację, po usunięciu prostych przeszkód. Jest to niejako wyleczenie przed podjęciem leczenia. Brak sukcesu powoduje przejęcie postępowania przez lekarzy i rozpoczęcie diagnostyki hormonalnej oraz technikami ultrasonograficznymi, laparoskopią i innymi. Jeśli uda się rozpoznać chorobę organiczną będącą przyczyną niepłodności, leczy się ją, jeśli nie, wprowadza się terapię hormonalną „z cyklu na cykl” oraz leczy się dysfunkcję narządów docelowych. O ile wymienione działania nie przynoszą efektu, proponuje się parze małżeńskiej adopcję.

Zajście w ciążę, naturalne bez przenoszenia komórki jajowej poza organizm kobiety, jest fundamentalna cechą naprotechnologii. Nie ma nadmiaru i mrożenia zarodków, ich ewentualnej śmierci i wpływu techniki na zwiększenie występowania wad wrodzonych u dziecka. Naprotechnologia leczy przyczyny niepłodności, tzn. choroby, które są lub mogą być przyczyną zaburzeń zdrowia i dolegliwości bólowych, np. endometriozę, hypotyreozę, zespół napięcia przedmiesiączkowego, bolesne miesiączkowanie i inne. Nie ma przy tym „ryzyka genetycznego" związanego ze stosowaniem techniki hyperstymulacji jajników i metod laboratoryjnych, w tym mrożenia embrionów. Nie ma sztucznej aborcji i redukcji płodów, częstość wad wrodzonych jest na poziomie naturalnym, podobnie jak częstość występowania ciąży mnogiej. W przypadku stwierdzenia niepłodności pochodzenia męskiego leczy się mężczyznę, przy czym nasienie pobiera się przy użyciu kolektora, umożliwiając tym samym równoległe, ewentualne mimo występujących problemów zapłodnienie naturalne.

Naprotechnologia jest systemem naturalnym, jest „wolniejsze” niż ART., jak to bywa z naturą, ale ,ekologiczne”. Hilgers ${ }^{19}$ informuje o skutecznym NaPro po dwóch nieudanych próbach in vitro $\mathrm{w}$ grupie pacjentek do 37. roku życia z odsetkiem żywych urodzeń około $40 \%$. Po 12 miesiącach leczenia uzyskuje się $44 \%$ ciąż, po 24 miesiącach $62 \%$ ciąż, a po 48 miesiącach $71 \%$

${ }^{19}$ T.W. Hilgers, The medical and surgical practice of NaProTechnology. 
ciąż. Przy niepowodzeniach proponuje się adopcję dziecka - wliczając ją, po 5 latach $90 \%$ małżeństw ma własne dziecko ${ }^{20}$.

Naprotechnologia spotyka się z wyjątkowym i bezprzykładnym sprzeciwem i atakiem ze strony środowisk ginekologicznych i politycznych. Sądzę, że podstawowym powodem jest widzenie przez naprotechnologię człowieka jako istoty duchowo biologicznej - co jest niezgodne z poglądami wielu ginekologów uznających to stanowisko za wpływ religii na postępowanie medyczne - i upolitycznienie tego problemu. Naprotechnologia spowodowała podział środowiska ginekologów, którego podstawą jest widzenie życia człowieka jako „święte”, a nie tylko „użyteczne”. Wywołuje to gwałtowny protest ludzi o odmiennych poglądach, głównie ateistycznych.

Jednym z zarzutów wobec naprotechnologii jest niewielka ilość danych na temat tej techniki w Internecie. Są tego co najmniej dwie przyczyny: NaPro jest systemem operującym szeregiem metod rozpoznawczych i leczniczych, na temat których można odszukać setki publikacji, ale niewystępujących pod hasłem ,naprotechnologia”. Badania nad naprotechnologią trwają i zapewne zaowocują publikacjami. Jest to system nowy w porównaniu z ART i AI. Poczekać więc należy na następne doniesienia na ten temat.

Ponieważ stosowanie technik wspomagania reprodukcji związane jest z dużymi zyskami finansowymi, spotyka się wiele nieuczciwych i nierzetelnych informacji zarówno o in vitro, jak i naprotechnologii.

\section{Wnioski}

W opinii autora w obecnej sytuacji pary małżeńskie chcące się leczyć z powodu niepłodności powinny otrzymać rzetelną i uczciwą medyczną informację na temat ART (in vitro) i „NaPro” - czyli na temat metod wspomagania reprodukcji oraz metod wspomagania prokreacji. Osoby wierzące powinny poradzić się duchownego. Ostatecznie decyzja jakie postępowanie wybiorą należy do nich.

\section{NATURAL CONCEPTION, “IN VITRO” AND "NAPRO”}

\section{Summary}

Infertility has been a big problem since the beginning of human existence. Some causes of infertility have always been present, other called "civilization causes" ap-

${ }^{20}$ Tamże. 
peared recently, causing an increased need for treatment, hence the assisted reproductive technologies (ART), including "in-vitro", have been introduced. Most children conceived with this method are healthy, but there is no doubt that it is a group of increased risk of various diseases. These methods are not accepted by the Catholic church, mainly because they involve killing or freezing of embryos regarded as human beings, but also for other reasons.

An alternative to "in vitro" are procreation methods defined as naprotechnology, free from the negative impact on the health of the newborn and mother, accepted by the Catholic church.

In the author's opinion, in the current situation, married couples who want to be treated for infertility should receive reliable and honest medical information about ART ("in vitro") -assisted reproductive methods and "NaPro" - assisted procreation methods. Believers should advise the priest. Ultimately, the decision which procedure they will choose belongs to them.

Słowa kluczowe: skutki technik wspomagania reprodukcji; wspomagana prokreacja; wcześniactwo; wady wrodzone

Keywords: consequences of assisted reproductive technologies; assisted procreation; prematurity; congenital anomalies

\section{BIBLIOGRAFIA}

Antsaklis A., Souka A.P., Daskalakis G., Papantoniou N., Koutra P., Kavalakis Y., Mesogitis S., Embryo reduction versus expectant management in triplet pregnancies, J Matern Fetal Neonatal Med. 2004 Oct;16(4), s. 219-222.

Arendt J., Schilling C., Peiffer M., Ginter S., Nahanb A.F., Lemosb C., Duboisb M., Thononb F., Jouanb C., Gaspardb O., Larcher M.E., Gomez V., Pereira S., Geimer M., Retrospective studies of pregnancies after assisted medical reproduction from 2001-2009 and Central Hospital in Luxembourg (part 2), Bull Soc Sci Med Grand Duche Luxemb. 2010;(2), s. 257-270.

Barrington K.J., Janvier A., The paediatric consequences of Assisted Reproductive Technologies, with special emphasis on multiple pregnancies, Acta Paediatr. 2013 Apr;102(4), s. 340-348.

Barnhart K.T., Assisted reproductive technologies and perinatal morbidity: interrogating the association, Fertil Steril. 2013 Feb;99(2), s. 299-302.

Bouillon C., Fauque P., Follow-up of children conceived by assisted reproductive technologies, Arch Pediatr. 2013 May; 20 (5), s. 575-579.

Buckett W.M., Chian R.C., Holzer H., Dean N., Usher R., Tan S.L., Obstetric outcomes and congenital abnormalities after in vitro maturation, in vitro fertilization, and intracytoplasmic sperm injection, Obstet Gynecol. 2007 Oct;110(4), s. 885-91.

Ceelen M., van Weissenbruch M.M., Prein J., Smit J.J., Vermeiden J.P., Spreeuwenberg M., van Leeuwen F.E., Delemarre-van de Waal H.A., Growth during infancy and early childhood in relation to blood pressure and body fat measures at age 8-18 years of IVF children and spontaneously conceived controls born to subfertile parents, Hum Reprod. 2009 Nov;24(11), s. 2788-2795.

Ceelen M., van Weissenbruch M.M., Vermeiden J.P., van Leeuwen F.E., Delemarre-van de Waal H.A., Pubertal development in children and adolescents born after IVF and spontaneous conception, Hum Reprod. 2008 Dec;23(12), s. 2791-2798. 
Chandra A., Martinez G.M., Mosher W.D., Abma J.C., Jones J., Fertility, family planning, and reproductive health of U.S. women: data from the 2002 National Survey of Family Growth, Vital Health Stat 23. 2005 Dec;(25), s. 1-160.

Cheang C.U., Huang L.S., Lee T.H., Liu C.H., Shih Y.T., Lee M.S., A comparison of the outcomes between twin and reduced twin pregnancies produced through assisted reproduction, Fertil Steril. 2007 Jul;88(1), s. 47-52. Epub 2007 Jan 30.

Cocchi G., Marsico C., Cosentino A., Spadoni C., Rocca A., De Crescenzo A., Riccio A., SilverRussell syndrome due to paternal H19/IGF2 hypomethylation in a twin girl born after in vitro fertilization, Am J Med Genet A. 2013 Oct;161A(10), s. 2652-2655.

Davies M.J., Moore V.M., Willson K.J., Van Essen P., Priest K., Scott H., Haan E.A., Chan A., Reproductive technologies and the risk of birth defects, N Engl J Med. 2012 May 10;366(19), s. 1803-1813.

Epelboin S., Patrat C., Luton D., Health and development of children conceived through assisted reproductive technologies, Rev Prat. 2014 Jan;64(1), s. 102-105. Review. French.

Farhangniya M., Dortaj Rabori E., Mozafari Kermani R., Haghdoost A.A., Bahrampour A., Bagheri P., Lancaster P.A.L., Ashrafi M., Vosough Taqi Dizaj A., Gourabi H., Shahzadeh Fazeli A., Comparison of Congenital Abnormalities of Infants Conceived by Assisted Reproductive Techniques versus Infants with Natural Conception in Tehran, Int J Fertil Steril. 2013 Oct;7(3), s. 217-224.

Feng C., Wang L.Q., Dong M.Y., Huang H.F., Assisted reproductive technology may increase clinical mutation detection in male offspring, Fertil Steril. 2008 Jul;90(1), s. 92-96.

Finnström O., Källén B., Lindam A., Nilsson E., Nygren K.G., Olausson P.O., Maternal and child outcome after in vitro fertilization--a review of 25 years of population-based data from Sweden, Acta Obstet Gynecol Scand. 2011 May;90(5), s. 494-500.

Gadzinowski J., Merritt T.A., Jopek A., Kochański A., Lavery A., Merritt T., In vitro babies - medical and legal aspects: a European and North American perspective, BioTechnologia vol. 93(1) C pp. 9-26 C 2012.

Grabar V.V., Interconnection between assisted reproductive technologies, pregnancy complications and risk of birth defects, Georgian Med News. 2014 Feb;(227), s. 7-14.

Gupta P., Nayan N., Sharma M., Perinatal outcomes among children born by assisted reproductive techniques-a hospital-based case control study, Med J Armed Forces India. 2012 Apr;68(2), s. $132-135$.

Hansen M., Bower C., The impact of assisted reproductive technologies on intra-uterine growth and birth defects in singletons, Semin Fetal Neonatal Med. 2014 Aug;19(4), s. 228-233.

Hansen M., Bower C., Milne E., de Klerk N., Kurinczuk J.J., Assisted reproductive technologies and the risk of birth defects--a systematic review, Hum Reprod. 2005 Feb;20(2), s. 328-338. Epub 2004 Nov 26.

Heisey A.S., Bell E.M., Herdt-Losavio M.L., Druschel C., Surveillance of congenital malformations in infants conceived through assisted reproductive technology or other fertility treatments, Birth Defects Res A Clin Mol Teratol. 2015 Feb;103(2), s. 119-126.

Henningsen A.K., Loft A., Malchau S.S., Pinborg A., The prognosis for children born after assisted reproduction, Ugeskr Laeger. 2012 Oct 8;174(41), s. 2462-2466.

Hilgers T.W., The medical and surgical practice of NaProTechnology, Pope Paul VI Institute Press, Omaha, NE 2004.

Hiura H., Okae H., Miyauchi N., Sato F., Sato A., Van De Pette M., John R.M., Kagami M., Nakai K., Soejima H., Ogata T., Arima T., Characterization of DNA methylation errors in patients with imprinting disorders conceived by assisted reproduction technologies, Hum Reprod. 2012 Aug;27(8), s. 2541-2548.

Hoeijmakers L., Kempe H., Verschure P.J., Epigenetic imprinting during assisted reproductive technologies: The effect of temporal and cumulative fluctuations in methionine cycling on the DNA methylation state, Mol Reprod Dev. 2016 Feb;83(2), s. 94-107. 
Hua R., Song Y., Wu B., Ni H., Yang X., Guo Y., Li H., Quan S., Yu Y., Occupational, educational and residential factors are associated with the outcomes of in vitro fertilization-embryo transfer, Nan Fang Yi Ke Da Xue Xue Bao. 2016 Jan;36(1), s. 44-49.

Humphries L.A., Chang O., Humm K., Sakkas D., Hacker M.R., Influence of race and ethnicity on in vitro fertilization outcomes: systematic review, Am J Obstet Gynecol. 2016 Feb;214(2), s. 212.e1-212.e17.

Hyrapetian M., Loucaides E.M., Sutcliffe A.G., Health and disease in children born after assistive reproductive therapies, J Reprod Immunol. 2014 Dec;106, s. 21-26.

Kagami M., Nagai T., Fukami M., Yamazawa K., Ogata T., Silver-Russell syndrome in a girl born after in vitro fertilization: partial hypermethylation at the differentially methylated region of PEG1/MEST, J Assist Reprod Genet. 2007 Apr;24(4), s. 131-136.

Källén B., Finnström O., Lindam A., Nilsson E., Nygren K.G., Otterblad P.O., Congenital malformations in infants born after in vitro fertilization in Sweden, Birth Defects Res A Clin Mol Teratol. 2010 Mar;88(3), s. 137-143.

Kelley-Quon L.I., Tseng C.H., Janzen C., Shew S.B., Congenital malformations associated with assisted reproductive technology: a California statewide analysis, J Pediatr Surg. 2013 Jun;48(6), s. $1218-1224$.

Kessous R., Davidson E., Meirovitz M., Sergienko R., Sheiner E., The risk of female malignancies after fertility treatments: a cohort study with 25-year follow-up, J Cancer Res Clin Oncol. 2016 Jan;142(1), s. 287-293.

Kochański A., Merritt T.A., Gadzinowski J., Jopek A., The impact of assisted reproductive technologies on the genome and epigenome of the newborn, J Neonatal Perinatal Med. 2013;6(2), s. 101-108.

Kuentz P., Bailly A., Faure A.C., Blagosklonov O., Amiot C., Bresson J.L., Roux C., Child with Beckwith-Wiedemann syndrome born after assisted reproductive techniques to an human immunodeficiency virus serodiscordant couple, Fertil Steril. 2011 Jul;96(1), s. e35-38.

Lambertini M., Del Mastro L., Pescio M.C., Andersen C.Y., Azim H.A., Jr., Peccatori F.A., Costa M., Revelli A., Salvagno F., Gennari A., Ubaldi F.M., La Sala G.B., De Stefano C., Hamish Wallace W., Partridge A.H., and Anserini P., Cancer and fertility preservation: international recommendations from an expert meeting, BMC Med. 2016; 14:1.Published online 2016 Jan 4.

$\mathrm{Lu}$ Y.H., Wang N., Jin F., Long-term follow-up of children conceived through assisted reproductive technology, J Zhejiang Univ Sci B. 2013 May;14(5), s. 359-371.

Merritt T.A., Goldstein M., Philips R., Peverini R., Iwakoshi J., Rodriguez A., Oshiro B., Impact of ART on pregnancies in California: an analysis of maternity outcomes and insights into the added burden of neonatal intensive care, J Perinatol. 2014 May;34(5), s. 345-350.

Mozafari Kermani R., Nedaeifard L., Nateghi M.R., Shahzadeh Fazeli A., Ahmadi E., Osia M.A., Jafarzadehpour E., Nouri S., Congenital anomalies in infants conceived by assisted reproductive techniques, Arch Iran Med. 2012 Apr;15(4), s. 228-231.

Neuman G., Koren G., Mothersisk update: reproductive outcomes after assisted conception, Can Fam Physician. 2013 Jan;59(1), s. 33-34, 36.

Oliver V.F., Miles H.L., Cutfield W.S., Hofman P.L., Ludgate J.L., Morison I.M., Defects in imprinting and genome-wide DNA methylation are not common in the in vitro fertilization population, Fertil Steril. 2012 Jan;97(1), s. 147-53.e7.

Ooki S., Birth defects in singleton versus multiple ART births in Japan (2004-2008), J Pregnancy. 2011;2011, s. 285706.

Patchava S., Gelbaya T.A., Nardo L.G., Managing the complications associated with assisted reproductive technologies, Minerva Ginecol. 2009 Aug;61(4), s. 347-355.

Pinborg A., Henningsen A.K., Malchau S.S., Loft A., Congenital anomalies after assisted reproductive technology, Fertil Steril. 2013 Feb;99(2), s. 327-332.

Plowden T.C., Novak C.M., Spong C.Y., Disparities in obstetrical outcomes in ART pregnancies compared with natural conceptions, Semin Reprod Med. 2013 Sep;31(5), s. 340-346. 
Qin J., Wang H., Sheng X., Liang D., Tan H., Xia J., Pregnancy-related complications and adverse pregnancy outcomes in multiple pregnancies resulting from assisted reproductive technology: a meta-analysis of cohort studies, Fertil Steril. 2015 Jun;103(6), s. 1492-508.e1-7.

Reefhuis J., Honein M.A., Schieve L.A., Correa A., Hobbs C.A., Rasmussen S.A., Assisted reproductive technology and major structural birth defects in the United States, National Birth Defects Prevention Study, Hum Reprod. 2009 Feb;24(2), s. 360-366.

Rizzuto I., Behrens R.F., Smith L.A., Risk of ovarian cancer in women treated with ovarian stimulating drugs for infertility, Cochrane Database Syst Rev. 2013 Aug 13;(8):CD008215.

Schneider J., Lahl J., Kramer W., Long-term breast cancer risk following ovarian stimulation in young egg donors: a call for follow-up, research and informed consent, Reprod Biomed Online. 2017 May;34(5), s. 480-485.

Skora D., Frankfurter D., Adverse perinatal events associated with ART, Semin Reprod Med. 2012 Apr;30(2), s. 84-91.

Stone J., Eddleman K., Lynch L., Berkowitz R.L., A single center experience with 1000 consecutive cases of multifetal pregnancy reduction, Am J Obstet Gynecol. 2002 Nov;187(5), s. 1163-1167.

Strawn E.Y. Jr, Bick D., Swanson A., Is it the patient or the IVF? Beckwith-Wiedemann syndrome in both spontaneous and assisted reproductive conceptions,

Fertil Steril. 2010 Jul;94(2), s. 754.e1-2.

Tararbit K., Lelong N., Thieulin A.C., Houyel L., Bonnet D., Goffinet F., Khoshnood B., EPICARD Study Group, The risk for four specific congenital heart defects associated with assisted reproductive techniques: a population-based evaluation, Hum Reprod. 2013 Feb;28(2), s. 367-374.

Torok O., Lapinski R., Salafia C.M., Bernasko J., Berkowitz R.L., Multifetal pregnancy reduction is not associated with an increased risk of intrauterine growth restriction, except for very-highorder multiples, Am J Obstet Gynecol. 1998 Jul;179(1), s. 221-225.

Uyar A., Seli E., The impact of assisted reproductive technologies on genomic imprinting and imprinting disorders, Curr Opin Obstet Gynecol. 2014 Jun;26(3), s. 210-221.

Wilson C.L., Fisher J.R., Hammarberg K., Amor D.J., Halliday J.L., Looking downstream: a review of the literature on physical and psychosocial health outcomes in adolescents and young adults who were conceived by ART, Hum Reprod. 2011 May;26(5), s. 1209-1219.

Vettori D.J., Jairath P., A rare presentation of aplasia cutis congenita after feto-reduction in a trichorionic-triamniotic pregnancy, J Neonatal Perinatal Med. 2015;8(3), s. 275-281.

Vulliemoz N.R., McVeigh E., Kurinczuk J., In Vitro Fertilisation: Perinatal Risks and Early Childhood Outcomes, Hum Fertil (Camb). 2012 Jun;15(2), s. 62-68.

Tłumaczenie polskie: Zapłodnienie pozaustrojowe: powikłania $w$ okresie okołoporodowym $i$ we wczesnym dzieciństwie, „Medycyna Praktyczna Ginekologia i Położnictwo”, Nr 6, 2013.

Yin L., Hang F., Gu L.J., Xu B., Ma D., Zhu G.J., Analysis of birth defects among children 3 years after conception through assisted reproductive technology in China, Birth Defects Res A Clin Mol Teratol. 2013 Nov;97(11), s. 744-749.

Zechner U., Pliushch G., Schneider E., El Hajj N., Tresch A., Shufaro Y., Seidmann L., Coerdt W., Müller A.M., Haaf T., Quantitative methylation analysis of developmentally important genes in human pregnancy losses after ART and spontaneous conception, Mol Hum Reprod. 2010 Sep;16(9), s. 704-713.

JANUSz GAdzINowski, prof. dr hab. W 1976 roku ukończył specjalizację I stopnia z ginekologii i położnictwa. W 1978 ukończył specjalizację I stopnia z pediatrii z podspecjalizacją z neonatologii, a w 1984 specjalizację II stopnia z pediatrii. W roku 1993 został kierownikiem Kliniki Neonatologii (w charakterze profesora nadzwyczajnego) i pełni tę funkcje do dziś. W 1997 roku był pełniącym obowiązki kierownika nowo powstałej Katedry Neonatologii, w roku następnym został jej kierownikiem i pozostaje nim do dziś. 